\title{
ANALISIS PELAKSANAAN LAYANAN HIV/AIDS DI KLINIK VCT RSUD ADJIDARMO KABUPATEN LEBAK TAHUN 2014
}

\author{
Rery Kurniawati DI, M.Kes*
}

\begin{abstract}
Abstrak
Pintu masuk layanan HIV/AIDS adalah melalui deteksi dini terhadap faktor risiko HIV/AIDS. Satu-satunya cara untuk mengetahui status HIV seseorang adalah dengan melakukan tes HIV.Dengan demikianakan meningkatkan cakupan penemuan kasus-kasus HIV/AIDS sehingga dapat segera dilakukan upaya-upaya pencegahan penyebaran virus, pengobatan dan dukungan. RSUD Adjidarmo adalah rumahsakit rujukan di wilayah Kabupaten Lebak.Rumahsakit ini telah melakukan upaya-upaya pendeteksian kasus HIV melalui klinik VCT yang diresmikan pada bulan Oktober 2010.

Tujuan: melakukan analisis terhadap pelaksanaan layanan HIV/AIDS di klinik VCT RSUD Adjidarmo Kabupaten Lebak tahun 2014.

Desain: analisis dilakukan secara deskriptif kualitatif dengan metode wawancara mendalam. Subjek penelitian adalah pelaksana program HIV/AIDS RSUD Adjidarmo.

Metodologi: desain penelitian adalah kualitatif dengan metode wawancara mendalam (indept interview). Subyek penelitian adalah petugas (penanggungjawab kegiatan dan konselor) di klinik VCT RSUD Adjidarmo.Topik kajian dalam penelitian ini adalah pelaksanaan layanan di klinik VCT meliputi gambaran kasus, hambatan, dan peluang dalam pelaksanaan layanan kasus HIV/AIDS di RSUD Adjidarmo.

Hasil: layanan VCT bersifat pasif hanya menunggu rujukan dari klien yang dirawat di RSUD Adjidarmo yang mempunyai faktor risiko dan gejala AIDS. Layanan yang pasif ini terus berlangsung sampai dengan tahun 2014.Hal tersebut dikarenakan sarana, prasarana, dan petugas di klinik yang belum tersedia secara memadai.Klien yang terdeteksi HIV+ pada umumnya sudah memasuki tahap AIDS dan mendapatkan infeksi oportunistik.Pada awal diresmikan klinik VCT yaitu sejak Oktober 2010, pendanaan kegiatan-kegiatan HIV/AIDS didanai oleh Global Fund.Akan tetapi seiring berjalannya waktu, sejak awal tahun 2013bantuan tersebut tidak ada lagi.

Sebagian besar klien adalah rujukan karena infeksi Tuberkulosis.Berdasarkan pernyataan dari dokter RS jumlah klien dengan koinfeksi TB-HIV sebesar $60 \%$ dari total HIV+ yang terdeteksi.Besarnya kasus koinfeksi TB-HIV ini meningkatan risiko kematian yang lebih besar pada klien.

Hambatan: belum tersedianya sarana, prasarana, dan petugas yang memadai; Klinik VCT terbatas hanya melayani konseling dan tes HIV, sedangkan layanan CST untuk beberapa obat khusus contoh kasus pada pasien yang mengalami alergi obat masih belum tersedia; dana yg semula bergantung pada bantuan luar (Global Fund) sekarang tidak ada lagi; program HIV/AIDS belum menjadi prioritas di pemerintah daerah setempat.

Peluang peningkatan layanan: mengintegrasikan layanan TB-HIV sebagai masalah terbesar pada penemuan kasus HIV/AIDS di RSUD Adjidarmo, petugas dilatih deteksi faktor risiko HIV pada klien TB dan melakukan PICT. Harapannya kajian ini menjadi dasar untuk advokasi pada pihak-pihak yang mempunyai peran penting di pemerintahan, pihak swasta, maupun organisasi masyarakat agar memberikan dukungan dalam peningkatan layanan HIV/AIDS.
\end{abstract}

Kata kunci: layanan HIV/AIDS, klinik VCT, deteksi faktor risiko.

* Poltekkes Kemenkes Banten 


\title{
ANALYSIS OF HIV / AIDS SERVICES AT VCT CLINICS OF ADJIDARMO HOSPITALIN DISTRICT LEBAK YEAR 2014
}

\author{
Rery Kurniawati DI, M. Kes *
}

\begin{abstract}
Entry point of HIV/AIDS service is through early detection of risk factors of HIV/AIDS. The only way to know one's HIV status is to perform an HIV test. Thereby could increasing the coverage of HIV/AIDS cases so that they can immediately made efforts to prevent the spread of the virus, treatment and support. Adjidarmo Hospital is a referral hospital in the district of Lebak. This hospital has made efforts detection of HIV through VCT clinic was inaugurated in October 2010.

Objective: To analysis the implementation of HIV/AIDS services at VCT clinic of Adjidarmo Hospital in Lebak District in 2014.

Design: Qualitative descriptive analysis was performed with in-depth interviews. Subjects were implementing of HIV / AIDS programs at Adjidarmo Hospital.

Methodology: The research design is qualitative with in-depth interviews method. Subjects were officers (responsible for the activities and counselors) in VCT clinic of Adjidarmo Hospital. Topics in this research study is the implementation of VCT services at the clinic include an overview of the case, barriers, and opportunities in the implementation of service HIV / AIDS cases in hospitals Adjidarmo.

Results: VCT services are only passively wait for referral of clients treated in hospitals Adjidarmo wich have a risk factors and symptoms of AIDS. This passive services continued until 2014 That is because the infrastructure, facilities, and personnel at the clinic are not adequately available. Clients who detected HIV + in general has entered the stage of AIDS and getting opportunistic infections. At the beginning of the VCT clinic was inaugurated in October 2010, the funding of the activities of the HIV / AIDS funded by the Global Fund. But over time, since the beginning of 2013 is no longer aid.

Most of the clients are referrals because of tuberculosis infection. Based on the statements of the doctors RS number of clients with TB-HIV by $60 \%$ of the total HIV + are detected. The amount of cases of TB-HIV co-infection is increasing the risk of death was greater in the client.

Barriers: the unavailability of facilities, infrastructure, and personnel are adequate; VCT clinics serve only limited counseling and HIV testing, whereas CST services for some special drug case in patients with drug allergies is still not available; funds that previously relied on outside help (the Global Fund) is now no longer exists; HIV / AIDS has not been a priority in local government.

Service improvement opportunities: integrating TB-HIV services as the biggest problem in the discovery of HIV / AIDS cases in hospitals Adjidarmo, officers trained in the detection of risk factors for HIV and TB clients do PICT. The hope of this study became the basis for advocacy to the parties that have an important role in government, the private sector, and civil society organizations in order to support the increase in HIV / AIDS services.
\end{abstract}

Keywords: HIV / AIDS, VCT clinics, detection of risk factors. 


\section{Pendahuluan}

Berbagai upaya untuk menanggulangi HIV/AIDS di Indonesia telah dilakukan, terlebih sejak ditetapkannya PerPres 75/2006.Laporan KPAN juga mencatat berdasarkan layanan mulai dari tingkat pusat hingga kabupaten/kota diketahui bahwa tidak ada propinsi di Indonesia yang bebas HIV.Indonesia sendiri merupakan negara dengan laju epidemic HIV tercepat di ASEAN.

Indonesia secara kumulatif berdasarkan laporan dari propinsi setiap triwulan oleh Kemenkes sampai dengan 2010 tercatat 22.726 kasus HIV/AIDS.Indonesia sudah menjadi urutan kelima di Asia yang paling berisiko HIV/AIDS.Perkiraan pakar jumlah kasus HIV/AIDS $\begin{array}{lll}\text { sudah mencapai } & 130.000\end{array}$ orang.Sedangkan berdasarkan estimasi dari KPAN (2010) jumlah ODHA di Kabupaten Lebak adalah 130 orang $(70$ penasun, 20 pelanggan WPS, 20 MSM, 10 WPS, dan 10 pasangan penasun). Di RSUD Adjidarmo, berdasarkan data tahun 2010, setiap bulan dilaporkan kasus baru HIV+.
Pintu masuk layanan penanggulangan HIV/AIDS adalah melalui deteksi dini terhadap faktor risiko. Satu-satunya cara untuk mengetahui status HIV seseorang adalah dengan melakukan tes HIV. Dengan optimalisasi deteksi dini akan meningkatkan cakupan penemuan kasus-kasus HIV/AIDS sehingga dapat segera dilakukan upaya-upaya pencegahan penyebaran virus, pengobatan dan dukungan.

RSUD Adjidarmo adalah rumahsakit rujukan di wilayah Kabupaten Lebak.Rumahsakit ini telah melakukan upaya-upaya pendeteksian kasus HIV melalui klinik VCT yang diresmikan pada bulan Oktober 2010.Yang melatarbelakangi dibentuknya klinik VCT karena ditemukannya kasus pasien dengan HIV+ sebelumnya.Akan tetapi karena belum terdapat layanan untuk HIV/AIDS sehingga laporan kasus sebelum Oktober 2010 sulit diketahui.

Sejak peresmiannya, klinik VCT RSUD Adjidarmo telah melaporkan kasus-kasus HIV/AIDS 
setiap bulannya. Melalui penemuan kasus ini, banyak hal yang dapat dikaji untuk mempelajari perkembangan kasus HIV/AIDS di Kabupaten Lebak dan melihat kemungkinan program/layanan yang efektif untuk pencegahan dan penanggulangannya. Kajian penemuan kasus ini juga menjadi sangat penting, mengingat bahwa jika ODHA tidak terdeteksi dan terabaikan dari layanan kesehatan maka besar kemungkinan virus HIV akan menyebar tidak hanya pada most at risk population (MARP) akan tetapi juga ke populasi umum. Oleh karena itu harapan yang ingin dicapai, kajian ini dapat dijadikan dasar untuk advokasi pada pihakpihak yang mempunyai peran penting di pemerintahan, petugas kesehatan, tokoh kunci masyarakat maupun masyarakat umum untuk peduli dan berperan serta dalam pencegahan dan penanggulangan HIV/AIDS di Kabupaten Lebak.

Tujuan penelitian ini adalah untuk melakukan analisis terhadap pelaksanaan layanan HIV/AIDS di klinik VCT RSUD Adjidarmo Kabupaten Lebak pada tahun 2014. Permasalahan dalam penelitian ini adalah belum diketahuinya pelaksanaan layanan HIV/AIDS di klinik VST RSUD Adjidarmo yang meliputi gambaran kasus, hambatan dan peluang.

Manfaat penelitian ini bermanfaat sebagai evaluasi berbasis data bagi pelaksana klinik VCT RSUD Adjidarmo khususnya dan masukan bagi pelaksanaan program pencegahan dan penanggulangan HIV/AIDS pada masyarakat umum di Kabupaten Lebak.

\section{Metode Penelitian}

Desain penelitian adalah kualitatif.Metode kualitatif yaitu proses berpikir yang dimulai dari data yang dikumpulkan kemudian diambil kesimpulan secara umum. Metode inipenelitian tidak membatasi penelitian pada upaya penerimaan atau penolakan dugaandugaan saja melainkan mencoba memahami situasi sesuai dengan situasi yang muncul.Ciri khusus metode kualitatif adalah pengungkapan fenomena tanpa harus 
menyajikan penjelasan-penjelasan kuantitatif.Tujuan penelitian kualitatif adalah mengembangkan konsep-konsep yang membantu pemahaman lebih mendalam atas fenomena sosial dan perilaku dalam setting alamiah dalam arti peneliti tidak berusaha untuk memanipulasi setting penelitian melainkan melakukan studi terhadap suatu fenomena dimana fenomena tersebut ada.

Pengambilan data dilakukan dengan dengan metode wawancara mendalam (indept interview).Wawancara mendalam adalah cara yang digunakan peneliti untuk mendapatkan keterangan secara lisan dari responden, dengan bercakap-cakap dan berhadapan muka dengan responden. Wawancara mendalam dilakukan untuk mendapatkan keterangan tentang diri pribadi, pendirian atau pandangan dari responden yang diwawancarai. Metode ini memungkinkan peneliti mendapat data atau informasi yang lebih alami dalam suasana subyek

Untuk rancangan kualitatif ditentukan obyek dan subyek penelitian. Dalam penelitian kualitatif sampling bukan ditujukan untuk generalisasi atau menggambarkan karakteristik populasi, melainkan bertujuan untuk menggambarkan fenomena sosial dari asumsi tentang realitas yang bersifat unik dan komplek.Oleh karenanya besar sampel dalam penelitian kualitatif tidak memperhitungkan jumlahnya.

Obyek

penelitian sebagaimana tergambar dalam rumusan masalah penelitian yaitu pelaksanaan layanan HIV/AIDS di klinik $\quad$ VCT $\quad$ RSUD Adjidarmo.Obyek yang menjadi kajian dalam penelitian ini adalah pelaksanaan layanan di klinik VCT meliputi gambaran kasus, hambatan, dan peluang dalam pelaksanaan layanan kasus HIV/AIDS di RSUD Adjidarmo.Subyek penelitian adalah pihak-pihak baik sebagai pelaku maupun pihak lain yang memahami informasi tentang obyek penelitian (rich informan). Subyek yang dianggap memahami dan mempunyai informasi yang kaya mengenai obyek tersebut adalah petugas (penanggungjawab kegiatan 
dan konselor) di klinik VCT RSUD Adjidarmo.

Analisis data kualitatif menggunakan metode analisis isi (content analysis) yaitu metode yang mengidentifikasi menganalisis dan melaporkan pola-pola yang ada berdasarkan data yang terkumpul.Langkahnya meliputi pengumpulan data, reduksi data, verifikasi kemudian disajikan dalam bentuk deskriptif dengan mengikuti pola induktif.

\section{Gambaran Umum RSUD}

\section{Adjidarmo Kab. Lebak}

1. Managemen

Rumah Sakit Umum Daerah dr. Adjidarmo Berdasarkan Keputusan Menteri Kesehatan Nomor 651/Menkes/SK/VII/2008 Republik Indonesia Tanggal 16 Juli 2008 tentang Penetapan Kelas Rumah Sakit Umum Daerah Dr Adjidarmo milik pemerintah Kabupaten Lebak Provinsi Banten, Yang ditindaklanjuti Peraturan Daerah Nomor 10 Tahun 2008 tentang pembentukan, organisasi dan tata kerja RSUD dr. Adjidarmo, maka struktur organisasi tata kerja
RSUD dr. Adjidarmo Kabupaten Lebak mengalami peningkatan kelas dari kelas $\mathrm{C}$ menjadi kelas B.

2. Pola Penyakit 10 Besar

Tabel 1.

Pola Sepuluh Besar Penyakit Rawat Jalan

Di RSUD dr Adjidarmo Kab Lebak Tahun 2009

\begin{tabular}{|c|l|c|c|}
\hline No & Nama Diagnosa & Jumlah & Persen \\
\hline 1 & $\begin{array}{l}\text { Tuberkulosis tanpa } \\
\text { Konfirmasi } \\
\text { histologi (TBC / } \\
\text { KP) }\end{array}$ & 8.033 & 11,26 \\
\hline 2 & Abses Gigi & 4.372 & 6,13 \\
\hline 3 & Diabetes melitus & 4.014 & 5,62 \\
\hline 4 & Karies Gigi & 3.010 & 4,22 \\
\hline 5 & Esensial Hipertensi & 3.009 & 4,22 \\
\hline 6 & ISPA Unspecipied & 2.609 & 3,66 \\
\hline 7 & Dispepsia & 2.421 & 3,39 \\
\hline 8 & Arthritis & 1.554 & 2,18 \\
\hline 9 & Asma & 1.328 & 1,86 \\
\hline 10 & $\begin{array}{l}\text { Penyakit Paru } \\
\text { Obstruktif Kronik }\end{array}$ & 1.207 & 1,69 \\
\hline \multicolumn{3}{|l|}{ Sumber: Data Rekam Medik RSUD dr.Adjidarmo }
\end{tabular}

\section{Hasil dan Pembahasan}

1. Gambaran Klinik VCT RSUD Adjidarmo

a. Managemen

$$
\text { Klinik VCT RSUD }
$$

Adjidarmo diresmikan pada bulan Oktober 2010.Sampai dengan Oktober 2014, petugas di klinik ini terdiri dari 2 orang dokter dan 1 orang perawat yang dilatih sebagai konselor.Salah satu dokter tersebut 
sekaligus sebagai penanggungjawab pelaksana klinik VCT. Sampai dengan September 2014 petugas di klinik VCT bertambah yaitu petugas analis 1 orang, administrasi 2 orang, farmasi 1 orang dan 2 orang petugas CST yang terdiri dari 1 dokter dan 2 perawat. Total petugas klinik VCT saat ini adalah 10 orang. Petugas tersebut selain bertugas di klinik VCT juga mempunyai tugas di unit pelayanan lain di RS Adjidarmo.Misalnya selain sebagai konselor bertugas juga sebagaidokter umum yang mempunyai tugas harian di layanan poliklinik umum, dan tugas struktural rumahsakit.Demikian juga dengan perawat, analis, dan petugas administrasi.

Ruangan klinik VCT ada secara khusus dan layanannya dibuka setiap hari.Akan tetapi karena sifat layanannya pasif berupa rujukan dari ruangan, maka ruangan tersebut hanya digunakan jika ada kasus yang ditangani.Sarana dan prasarana di klinik ini terdiri dari ruang tunggu, ruang konseling dan layanan, fasilitas untuk melakukan pemeriksaan fisik, media-media KIE HIV/AIDS.

b. Target Populasi Layanan Klinik VCT RSUD

Adjidarmo

Masyarakat dengan faktor risiko HIV/AIDS baik rujukan maupun umum yang dengan sukarela mau melakukan tes HIV adalah sasaran target layanan klinik VCT. Pada pelaksanaannya klien yang dilakukan VCT adalah rujukan dari klien yang dirawat di RSUD Adjidarmo dengan penyakit infeksi dan dicurigai mempunyai gejala AIDS dan perilaku berisiko.Sedangkan klien di luar rumahsakit yang datang untuk tes HIV belum ada.

Klien yang dirujuk ke klinik VCT sebagian besar karena Tuberculosis, kemudian diare, dan gangguan lainnya. Tidak terdapat data rinci berapa jumlah klien dari masing-masing penyakit tersebut, akan tetapi keterangan dari dokter rumahsakit diperkirakan $60 \%$ adalah infeksi Tuberculosis. 
c. Metode Layanan Klinik VCT

Walaupun dibuka setiap hari akan tetapi karena layanan sifatnya masih pasif yaitu menunggu rujukan dari klien yang dirawat di rumahsakit maka layanan baru dilakukan jika ada rujukan saja. Sementara itu dokter dan petugas lainnya melaksanakan kegiatan lain sesuai dengan tugasnya diluar klinik VCT.

Pada awal pembentukannya, layanan yang diberikan diklinik VCT sebatas konseling untuk tes HIV dan pencegahan perilaku berisiko, selanjutnya jika ditemukan kasus HIV+ dan memerlukan pengobatan ARV maka klien tersebut akan dirujuk ke RSUD Serang yang merupakan salahsatu rumahsakit rujukan di Propinsi Banten. ARV belum tersedia di klinik VCT RSUD Adjidarmo karena klinik ini masih baru diresmikan dan dianggap kasus yang ditemukan masih relative sedikit.Akan tetapi sejak 2013, obatobatan untuk penderita HIV+ sudah bisa didapatkan di klinik VCT RSUD Adjidarmo.Meski demikian rangkaian pengobatan yang harus berkesinambungan bagi penderita HIV+ belum bisa dilakukan karena jangkauan jarak rumah sakit dari tempat tinggal pasien yang relatif jauh. Meski obat didapat secara gratis akan tetapi biaya transportasi dan jarak yang jauh adalah kendala utama tidak hanya pada pengobatan HIV/AIDS. Ditunjang pula dengan kesadaran yang rendah dari masyarakat tentang pencegahan dan pengobatan HIV/AIDS sehingga perlu upaya peningkatan kesadaran akan pentingnya mengetahui cara pencegahan dan pengobatan HIV/AIDS bagi masyarakat pada umumnya.

\section{d. Penemuan Kasus di Klinik VCT}

Berdasarkan estimasi dari KPAN jumlah ODHA di Kabupaten Lebak adalah 130 orang (70 penasun, 20 pelanggan WPS, 20 MSM, 10 WPS, dan 10 pasangan penasun).Berikut ini adalah laporan penemuan kasus HIV/AIDS di klinik VCT RSUD Adjidarmo sejak Oktober 2010 s.d Maret 2011. 
Tabel 2. Laporan Kasus HIV/AIDS

\begin{tabular}{|c|l|c|c|c|c|c|c|c|}
\hline $\begin{array}{c}\text { N } \\
\text { o }\end{array}$ & $\begin{array}{l}\text { Variab } \\
\text { el }\end{array}$ & $\begin{array}{c}\text { O } \\
\text { kt }\end{array}$ & $\begin{array}{l}\text { N } \\
\text { ov }\end{array}$ & $\begin{array}{c}\text { D } \\
\text { es }\end{array}$ & $\begin{array}{c}\text { J } \\
\text { a } \\
\text { n }\end{array}$ & $\begin{array}{c}\text { F } \\
\text { e } \\
\text { b }\end{array}$ & $\begin{array}{c}\text { M } \\
\text { ar }\end{array}$ & $\begin{array}{c}\text { To } \\
\text { tal }\end{array}$ \\
\hline 1 & $\begin{array}{l}\text { Jml } \\
\text { klien } \\
\text { yg } \\
\text { berku } \\
\text { njung }\end{array}$ & 1 & 10 & 4 & 1 & 1 & 9 & 63 \\
\hline 2 & $\begin{array}{l}\text { Klien } \\
\text { laki- } \\
\text { laki }\end{array}$ & 9 & 8 & 3 & 7 & 1 & 7 & 48 \\
\hline 3 & $\begin{array}{l}\text { Klien } \\
\text { perem } \\
\text { puan }\end{array}$ & 1 & 2 & 1 & 4 & 5 & 2 & 15 \\
\hline 4 & HIV + & 5 & 3 & 0 & 5 & 6 & 2 & 21 \\
\hline 5 & $\begin{array}{l}\text { Klien } \\
\text { yg } \\
\text { diruju } \\
\text { k CST }\end{array}$ & 5 & 3 & 0 & 4 & 5 & 2 & 19 \\
\hline 6 & $\begin{array}{l}\text { Menin } \\
\text { ggal }\end{array}$ & 1 & 1 & 0 & 1 & 1 & 1 & 5 \\
\hline 7 & $\begin{array}{l}\text { Bumil } \\
\text { yg } \\
\text { HIV + }\end{array}$ & 0 & 0 & 0 & 0 & 0 & 0 & 0 \\
\hline
\end{tabular}
Adjidarmo, Maret 2011.

Selain data diatas dilaporkan juga data yang menunjukkan jumlah HIV+ pada usia reproduksi yang tinggi yaitu 11 orang (58\%) dari total 19 ODHA. Sedangkan jumlah ODHA pada kategori kelompok berisiko adalah pelanggan PS 4 orang, pasangan risiko tinggi 4 orang, dari total sebanyak 23 orang.Dari kelompok berisiko lainnya seperti WPS, PPS, waria, LSL, IDU, WBP tidak ada data yang dilaporkan.

$\begin{array}{rrrr} & \text { Setiap } & \text { bulan } & \text { dilaporkan } \\ \text { kasus } & \text { baru } & \text { HIV+ } & \text { hal ini }\end{array}$

mengindikasikan adanya perilaku berisiko di masyarakat yang perlu mendapat penanganan untuk pencegahan penyebaran virus. Jumlah total yang tercatat sejak Oktober 2010 s.d Maret 2011 adalah 21 orang. Dibandingkan dengan estimasi jumlah ODHA di Kabupaten Lebak sebanyak 130 maka capaian cakupan baru sekitar 16\%.Pencapaian ini terkesan lambat apalagi jika melihat fenomena gunung es kasus HIV/AIDS maka jumlah sebenarnya yang belum terdeteksi jauh lebih banyak.

Lambatnya penemuan kasus juga karena layanan VCT yang bersifat pasif hanya menunggu rujukan dari klien yang dirawat di RSUD Adjidarmo dengan adanya factor risiko dan gejala AIDS. Layanan yang pasif ini karena sarana, prasarana, dan petugas khusus di klinik yang belum tersedia secara memadai.Yang penting untuk mendapat perhatian adalah bahwa klien yang terdeteksi HIV+ merupakan klien yang sudah memasuki tahap AIDS dan mendapatkan infeksi oportunistik.Dengan asumsi bahwa 
klien tersebut telah terinfeksi HIV sejak 5 s.d 10 tahun maka ada kemungkinan klien tersebut telah menyebarkan virus pada orang lain jika melakukan perilaku berisiko. Oleh karena itu pasangan dan orangorang yang terdampak risiko juga perlu dideteksi terhadap kemungkinan tertular virus HIV.

Rasio laki-laki dan perempuan yang terdeteksi HIV+ adalah 3:1.Keadaan ini memerlukan penanganan program yang dapat menjangkau laki-laki yang berisiko. Selanjutnya deteksi juga dilakukan pada pasangan tetap dan orang-orang yang terdampak risiko sehingga penemuan kasus pada perempuan juga akan meningkat.

Sebagian besar klien yang dirujuk ke klinik VCT adalah klien yang mengalami infeksi Tuberkulosis. Data rinci mengenai jumlah yang terinfeksi TB tidak tersedia, akan tetapi berdasarkan pernyataan dari dokter yang memberi layanan VCT jumlah klien dengan koinfeksi TB-HIV adalah berkisar $60 \%$ dari total HIV+ yang terdeteksi. Besarnya kasus koinfeksi TB-HIV ini perlu mendapat layanan yang lebih komprehensif dan efektif mengingat peningkatan risiko kematian yang lebih besar pada klien.

Koinfeksi lainnya seperti IMS-HIV tidak terdapat data karena di RSUD Adjidarmo belum mempunyai klinik yang melayani IMS.Hal tersebut terkendala karena belum ada dokter spesialis kulit kelamin yang bertugas di RSUD Adjidarmo. Walaupun telah dilakukan sosialisasi tentang IMS dan HIV baik pada dokter-dokter RS maupun petugas di Puskesmas akan tetapi laporan kasus IMS sangat sedikit. Berdasarkan keterangan dokter RS, sedikitnya laporan kasus IMS kemungkinan juga dipengaruhi oleh keengganan masyarakat untuk memeriksakan penyakit yang berhubungan dengan alat kelaminya karena malu.

Kelompok berisiko yang belum terdata dalam laporan klinik VCT RSUD Adjidarmo seperti WPS, PPS, waria, LSL, IDU, WBP penting untuk dilakukan penjangkauan secara aktif. Karena jika hanya menunggu maka besar kemungkinan kelompok ini tidak 
akan mencari layanan terkait dengan stigma dan diskriminasi. Petugas di klinik VCT tidak dapat berbuat banyak dalam mengatasi masalah ini, karena dalam pelaksanaannya sangat diperlukan kerjasama lintas program dan dukungan pemerintah daerah, akan tetapi HIV/AIDS belum menjadi prioritas programprogram di pemerintahan sehingga terkesan masih terabaikan.

Keberadaan klinik VCT juga belum diketahui masyarakat umum.Karena pada awal pendiriannya, klinik ini dibentuk untuk menangani kebutuhan pelayanan kasus HIV/AIDS yang terdeteksi dari klien yang dirawat di RSUD Adjidarmo saja.Masyarakat di Kabupaten Lebak sendiri belum menyadari tentang keberadaan HIV/AIDS apalagi terpapar dengan informasi HIV/AIDS. Hal ini seperti dikemukakan oleh dokter RS bahwa pada saat dilakukan konseling untuk tes HIV klien menurut saja dan menganggap hal tersebut merupakan pemeriksaan biasa seperti halnya pemeriksaan lain yang berhubungan dengan kondisi sakitnya.
2. Hambatan

Pelayanan klinik VCT di RSUD Adjidarmo yang berjalan sejak tahun 2010 ini dalam pelaksanaannya masih terdapat banyak hambatan dan tantangan yang besar antara lain:

- Belum tersedianya sarana, prasarana, dan petugas khusus yang memadai.

- Klinik VCT terbatas hanya melayani konseling dan tes HIV, sedangkan pelayanan lanjutan untuk CST dirujuk ke RSUD Serang di kota Propinsi.

- Terbatasnya dukungan dana.Sejak diresmikan tahun 2010 pembiayaan masih bergantung pada bantuan luar (Global Fund) dan pada awal tahun 2012 bantuan GF tidak ada lagi sehingga kegiatan-kegiatan mobile/keluar gedung seperti penjaringan di Lapas tidak dilakukan lagi.

- Informasi HIV/AIDS dan keberadaan klinik VCT di Kabupaten Lebak belum menyebar di masyarakat.

- Program-program pengendalian HIV/AIDS belum masuk 
prioritas dalam pemerintahan

daerah sehingga programprogram dukungan pun sangat kurang.

3. Peluang peningkatan layanan

Berdasarkan hambatan dan tantangan seperti telah dijelaskan diatas, peluang paling besar dan mungkin untuk dilaksanakan adalah mengintegrasikan layanan TB-HIV sebagai masalah terbesar pada penemuan kasus HIV/AIDS di RSUD Adjidarmo, petugas yang memberi layanan TB dilatih mengenai deteksi faktor risiko HIV pada klien TB dan melakukan PICT pada klien yang dicurigai berisiko HIV. Hal penting yang harus dilakukan yang mendahului pelaksanaan berbagai program adalah advokasi pada pihak-pihak yang mempunyai peran penting di pemerintahan, pihak swasta, maupun organisasi masyarakat agar memberikan dukungan dalam peningkatan layanan HIV/AIDS.Hasil analisis merupakan informasi yang dapat disampaikan dalam mengadvokasi pihak-pihak tersebut.

\section{Simpulan}

Kasus HIV/AIDS yang ditemukan di klinik VCT RSUD Adjidarmo hanyalah gambaran sebagian kecil dari kasus sebenarnya di masyarakat.Mengingat fenomena gunung es, dimana kasus-kasus yang belum terungkap jauh lebih banyak. Untuk itu perlu upaya-upaya untuk memecahkan fenomena gunung es ini antara lain melalui aktif mendeteksi faktor risiko untuk menemukan kasus-kasus baru dan promosi tentang HIV/AIDS di masyarakat.

Penemuan kasus HIV+ yang sebagian besar rujukan dari klien Tuberculosis, menunjukkan adanya koinfeksi TB-HIV yang selain berakibat pada beban pengobatan pada klien, juga berisiko kematian yang lebih besar.Koinfeksi TB-HIV memerlukan perhatian serius dan penanganan yang lebih sulit, penanganan masalah ini memerlukan integrasi layanan yang efektif.

Pelayanan klinik VCT di RSUD Adjidarmo juga belum optimal karena petugas yang belum ada secara khusus bertugas melaksanakan pelayanan di klinik 
VCT, fasilitas yang belum memadai, dan terutama belum ada layanan CST yang merupakan layanan lanjutan bagi ODHA. Dukungan biaya yang masih tergantung pada bantuan donator (Global Fund) juga membatasi pelaksanaan program.

1. Saran

Untuk meningkatkan pelaksanaan layanan klinik VCT di RSUD Adjidarmo, beberapa saran yang dapat dipertimbangkan adalah:

- Meningkatkan fasilitas layanan dan kapasitas petugas untuk meningkatkan pelayanan di klinik VCT yang optimal.

- Memberikan pelatihan bagi tenaga medis dan paramedik untuk mampu menggali faktor risiko HIV/AIDS.

- Mendekatkan layanan CST sebagai layanan berkesinambungan dari kasus HIV/AIDS melalui layanan di Puskesmas.

- Menggunakan informasi hasil analisis untuk melakukan advokasi kepada pemerintahan, pihak swasta, maupun organisasi masyarakat agar memberikan dukungan dalam peningkatan layanan HIV/AIDS.

\section{Daftar Pustaka:}

KPAN (2009). Strategi dan Rencana Aksi Nasional

Penanggulangan HIV dan

AIDS 2010-2014. Jakarta.

RSUD Dr. Adjidarmo (2011).

Rekam Medik RSUD

dr.Adjidarmo.Rangkasbitung:

Bag. Rekam Medik RSUD Dr.

Adjidarmo Lebak.

RSUD Dr. Adjidarmo (2011).

Laporan Klinik VCT RSUD

Adjidarmo. Rangkasbitung:

RSUD Dr. Adjidarmo Lebak.

Departemen Kesehatan (2007).

Surveilans Terpadu Biologis

Perilaku pada Kelompok

Berisiko. Jakarta: Depkes RI.

Depkes RI (2008). Statistik Kasus

HIV/AIDS di Indonesia.

Jakarta: Ditjen PPM \& PLP

Depkes RI.

Dinkes Prop. Banten (2009). Profil Kesehatan Propinsi Banten tahun. Serang: Dinkes Prop. Banten.

Dinkes Kabupaten Lebak (2011). Laporan P2M\&PL Tahun Lebak: Dinkes Kab.Lebak

Depkes RI (2011). Modul pelatihan konselor HIV/AIDS. Jakarta: Depkes R.I 
Depkes RI (2006). Pedoman

Pelayanan Konseling dan

Testing HIV/AIDS Secara

Sukarela (Voluntary

Councelling and Testing).

Jakarta: Dirjen P2\&PL.

Depkes RI.

Satori, Djam'an. Komariah, Aan

(2010). Metodologi Penelitian

Kualitatif, Bandung: Alfabeta 